\title{
Witchcraft of Saluang Sirompak: Music of Broken Hearts in the Taeh Baruah Minangkabau Community
}

\author{
Nil Ikhwana, ${ }^{\mathrm{a}, *}$ \\ a Institut Seni Indonesian, Surakarta, Jl. Ki Hajar Dewantara No 19, Surakarta, 57126 Indonesia \\ 1 ikhwansnil@gmail.com* \\ * corresponding author
}

\section{ARTICLE INFO}

Article history

Received 2020-08-30

Revised 2020-09-06

Accepted 2020-09-09

\section{Keywords}

Spirituality Music

Saluang Sirompak

Basirompak

Witchcraft

Broken Hearts

\begin{abstract}
Saluang Sirompak is a type of music with spiritual power in Taeh Baruah, Payakumbuh District, Lima Puluh Koto Regency, Minangkabau, West Sumatra. Saluang Sirompak is a show aimed at witchcraft, a woman who has insulted a man who wants to propose her. This witchcraft activity is known as Basirompak. The problem that was revealed was how the music of Saluang Sirompak affected women's mental disorders. The ethnographic method was used in this study - the data were obtained through observation and interviews with actors or musicians Saluang Sirompak. The analysis was carried out by paying attention to the function of music and the organology of the musical instruments as a powerproducing tone that can affect mental disorders for women who are the target victims. The conclusion that can be drawn is that witchcraft in Basirompak activities can distinguish what is right and what is wrong; If the women were not mistaken, they would not be victims of Basirompak's activities.
\end{abstract}

This is an open-access article under the CC-BY-SA license.

\section{Introduction}

Saluang Sirompak is part of the culture of the Taeh Baruah village children, Payakumbuh District. Sirompak comes from the word rompak, which means to break (dobrak), rob, loot, or take by force. This is a form of magical ritual ceremony performed by a sirompak pawang to conquer the heart of a woman who has insulted a man. The background of the legend of Saluang Sirompak in Taeh Baruah is the beginning of the unrequited love story of a poor young man with skin disease (leprosy) named Simbabau. Simbabau fell in love with a rich and beautiful girl named Puti Losuang Batu. The great desire to have Puti Losuang Batu, so one-day Simbabau ventured to express his wish. However, Simbabau was rejected by Puti Losuang Batu, and what happened was he was even scolded with dirty, low, offensive, and insulting words so that it was unbearable. With the incidents of throwing dirty, low, despicable, and insulting words, with feelings of shame and deep disappointment, Simbabau left Puti Losuang Batu without a definite direction and purpose.

Without realizing it, the night was approaching, and Simbabau began to vent all his frustration by reciting mantras in his chanted heart. These mantras are in the form of summoning spirits or devils that are roaming around him-Simbabau after reciting mantras repeatedly without realizing it until he is unconscious (trance). In a trance situation, Simbabau managed to collaborate with spirits and demons who heard the inner screams, then entered into a consensus. Spirits who are invited to cooperate can influence or conquer the feelings and thoughts of Puti Losuang Batu. Puti Losuang Batu is unconsciously not like a normal human being. The story shows that love and music are two inseparable things. However, the Saluang Sirompak phenomenon is different; the melody from the instrument has a negative effect because it injures women. Why? Because this is related to the story above, namely when a man loves a woman, but his love is rejected, and what he receives is 
humiliation, the man chooses to use music to take revenge. Music, in this case, is used for magical functions or is called witchcraft [1] [2]. Adinkrah has reviewed the use of music as witchcraft. The research was conducted in Ghana, West Africa. Adinkrah investigates the role of music in the acquisition, dissemination, and preservation of the ideology of Akan magic in Ghana, West Africa. Adinkrah's research addresses the problem of representation of magic in upper-class life and gospel music. Adinkrah took three examples of songs, critical analysis of the song lyrics, Adinkrah described the songs on the audio cassette purchased in Ghana, Adinkrah then translated them into English from the Akan language; the conclusion was that the Ghanaian beliefs about witches showed that music plays a supportive role in strengthening and spreading or transmitting magic belief [3].

Music as witchcraft is also used in analyzing the issue of social power in the political situation in America. The article written by Morris discusses the problem of typical American music culture; according to Morris, the music of the younger generation contains political power without having to be involved in certain political situations. Morris's research shows that music plays a magical role in many societies, music as witchcraft can turn individualism into anti-sociality, isolation into destruction, desire to violence. The conclusion of Morris's research shows that America is still possessed by the idea of music for magic [4]. Research conducted by Conrad never discussed this issue, but more on the issue of music and clinical effects. Conrad revealed that if music is a force that can slowly build up the individual soul, the power of music can also destroy illusions [5]. According to Conrad, music comes from magical acts that are not bound by natural paths. The evolution of music as therapy began as a critical element of healing in a mystical or ritual context. Today, Conrad argues, music is seen as an adjunct to overcome some of the environmental anonymity and deindividuation. According to Conrad, it is beneficial physiological effects of music, but music also has the potential to be detrimental because it is a disagreement with personal preferences. Music and hypnosis were also Marra's topics of discussion. Marra saw music and magic in the football game events. According to Marra, musical performances in soccer matches have a role in increasing sonic power as a trigger for causal relationships between events. For Marra, music serves as an axis of communication that connects the physical realm with the mystical or intangible dimension. Marra argues, if music is present in the middle of a match, fans who attend the music are believed to change the course of the match, disrupt the mood, the body, and, ultimately, the result.

Here the music becomes magic; music becomes mutual trust between fans and players, activated through good rituals. Marra concluded that music was a crucial feature in this process [6]. Pegg writes about the relationship between music and shamanism in Western Mongolia. Pegg considers research on folk beliefs and shamanism and activities surrounding the performance of the Western Mongolian epic and the power of epic texts, musical instruments (tovshuur), and poetry as new to him. Pegg sees religious syncretism in the text - the object of communist bowling - and the worship of epic heroes as gods. According to Pegg, his research contributes to debates on oral and textual traditions by considering the ritual performance of epic texts. This research shows that music and shamanism activities have become a continuous tradition; these traditions are related to matters of power and give each other influence. This article shows the direction of discussion about music, shamanism, and hypnosis [7]. The description of the research results above is a reference for this research because the above topics lead to issues of music, witchcraft, or shamanism. The problem, which is the focus of the analysis in this research, is how Saluang Sirompak is used in the shamanic tradition. This research chose the research location in Taeh Baruah Village because Taeh Baruah Village is the only place that has Saluang Sirompak music used in performances, and this activity is called Basirompak. Basirompak is a cultural event.

The cultural event in question is a woman's fault for saying inappropriate words so that men are hurt. Based on this feeling of hurt, the man asked for help from the perpetrator of Basirompak so that the woman was made mentally ill or crazy. Basirompak also involved several supporters apart from the Saluang Sirompak instrument, namely gasiang tangkurak, pantun/dendang, recitation of Al Quran verses, a series of offerings, and a unique tanjuang/Tanjung performance venue. Based on this description, this study aims to reveal how Saluang Sirompak is used as a medium to disturb women's souls - here, music functions as a means of conveying mystical and witchcraft messages. Dessen has previously revealed the function of music as a witchcraft transformation. According to Dessen, ascension is a radically diverse type of extensive group improvisation with the idea of music as a process of witchcraft transformation. This phenomenon shows that music is an artificial abstraction of a ritual where the cultural complex is a part. The potential value of applying this radical empirical approach is used to study music and magical powers [8]. The issue of negative sentiment in the 
Saluang Sirompak case is the keyword in this study because it is related to the negative response from men to women. Music and emotion towards women excessively produce negative attitudes. In this study, it can produce a shamanic tradition by making the play Saluang Sirompak as the medium. This study intends to reveal how the shamanic tradition using Saluang Sirompak can occur, is this tradition still being practiced at this time? Alternatively, is there a criticism of the tradition in today's contemporary era. Approximately the direction this research will lead there.

\section{Method}

This study focuses on the phenomenon of the spirituality of the Saluang Sirompak in Taeh Baruah, Minangkabau. Applying the scientific method in research practice requires a research design that follows the conditions and is balanced with the research to be carried out. The research design starts with the researcher's interest in the object under study; after the interest, the researcher looks for supporting data. In this study, an instrument in the form of an interview guide was used [9]. The interview technique used was free interviews and guided interviews. In Figure 1 is the situation when the researcher takes data from a Saluang Sirumpak player named Sayute. The researcher wore a dark blue shirt and trousers with Sayute. The interview stage was carried out very. Sayuti provided information about the functions of Saluang Sirompak in various positions, and especially the information extracted was the function of Saluang Sirumpak as a medium of witchcraft.

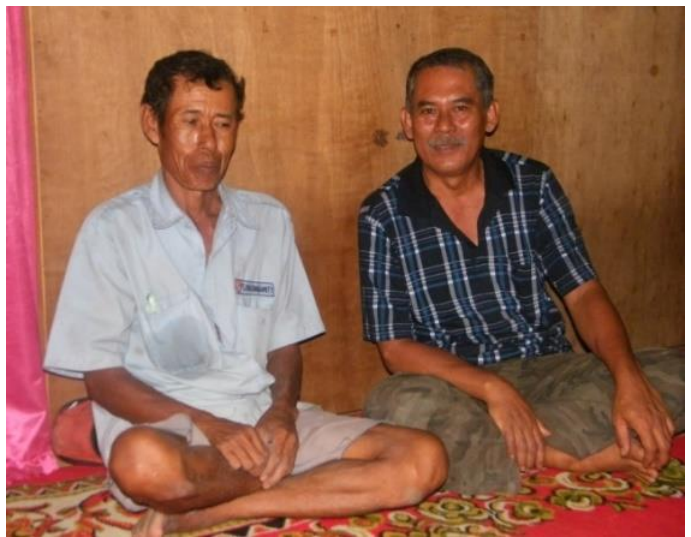

Fig. 1. A researcher with Sayute in the Process of Collecting Saluang Sirompak Data

Hockey states that in free interviews, informants are given the flexibility to answer various questions without any binding provisions that can lead to an informant's rigidity [10]. Selection of sources/informants prioritized Basirompak perpetrators, community leaders, village caregivers, traditional leaders, religious leaders, victim-witnesses, petitioner witnesses, and several people who knew in detail about Basirompak's activities in Taeh Baruah. Data analysis was carried out by systematically compiling various observations, interviews, and documents. The analysis is descriptive qualitative in nature and lasts throughout the study with steps, namely data reduction, data presentation, data interpretation, and concluding [11].

\section{Results and Discussion}

\subsection{Women in Minangkabau Culture}

There is a custom that gives its color to Kabupaten Lima Puluh Kota in the daily life of teenagers. In the afternoon, you can see young women dressed up neatly to be attractive to the eye. This is not something that is prohibited by the parents or local customary leaders. Parents advised their children not to stay locked up at home. Women usually travel not far from the location where they live and travel with their female friends.

In contrast to men, who are more aggressive, energetic, potential, and free to move. Thus men are more fortunate in taking advantage of time in the afternoon than women. This activity usually occurs around $3.30 \mathrm{pm}$ to $6.30 \mathrm{pm}$, or after the Asr prayer, and ends before the Maghrib prayer. One form of cultural event is behavior, which is the initial main idea to determine whether Basirompak can be carried out or not. The behavior in question is a pattern of the behavior of a young woman in interacting with the community in her environment, especially towards men. The customs in 
Minangkabau (including the Payakumbuh area) have guided the entire community in socializing. This is related to a traditional saying, which was pronounced by Dt. Rajo Penghulu: Nan tuo dihormati, nan ketek dikasihi, samo gadang baok bakawan, di nan baik bahimbauan, di nan buruak bahambauan, meaning: parents are respected, the little ones are loved, the same age is invited to be friends, about good news is conveyed, if a disaster comes to mutual help. In this proverb, the position of the youth is in the samo gadang bawo bakawan [12]. According to this view, adolescents have mutual respect, respect for the opinions of others, instill the nature of togetherness that is highly demanded in everyday life.

It is a must for Minangkabau adolescents to practice/implement the meaning of the saying, bajalan paliharokan kaki, bakato paliharokan lidah, kaki tataruang inai padahannyo, lidah tataruang ameh padahannyo. That is, walking, nurturing feet, saying nurture the tongue, must be brave enough to bear the consequences of one's actions or promises. There are three categories of women [13], simarewan, mambang tali awan, and parampuan. Simarewan can be defined as the type of woman who has a bad character. These traits are reflected in his daily behavior patterns, such as greedy like to have something more than necessary like to take the face, another mouth in his heart, lack of courtesy, lack of opinion, and do things that are not justified by custom and religion. The category of mambang tali awan is a woman who is proud, arrogant, big-mouthed, likes to visit, has no shame, does not have feelings as a woman, and likes to play one another. Whereas in the category of parampuan, it is a female figure who has good character and is always polite to others. In Minangkabau society, women's groups who can portray the community's views as praiseworthy women are also often dubbed as Bundo Kanduang [14].

\subsection{Men and Rejected Love}

Erianto, a Gasiang Tangkurak player, told his experience that a man was suffering from hurt feelings against a woman who had insulted him, and rejected the man's love roughly. This incident made a young man come to the Sirompak perpetrator to ask for help because of the pain he was enduring. Here, dialogue or negotiation takes place between the young man and the perpetrator, which, in essence, is conveying hurt against a teenage woman who insulted her and explaining the characteristics/identity of the woman. If there has been an agreement between the two parties, then the first requirement for the perpetrator of Sirompak is to ask for a picture of the woman's face in question. For this facial image, the young man usually gives a portrait/photo because, in witchcraft and the fluency of Basirompak, it will be easier to remember or imagine the face of the target that will be transformed through Simambau Hitam in the Sirompak activity. Concerning the costs required, the young man left a sufficient amount of money to meet Basirompak's initial needs. The Perpetrator gave an overview of the initial needs as the requirements he did, and the number of personnel who would be directly involved in the time frame provided. The total cost required during the activity will be conveyed by the perpetrator, after the women who will be targeted (as victims) in the Basirompak activity. However, it is possible that as long as the activities are carried out, they will come and pay off the required costs. Table 1 is the stage of implementing Basirompak until the process affects the victims.

Table 1. Basirompak process in Saluang Sirompak witchcraft

\begin{tabular}{ccc}
\hline Applicant & $\begin{array}{c}\text { Music Performance in } \\
\text { Basirompak }\end{array}$ & Target / victim \\
\hline $\begin{array}{c}\text { Requesting the Basirompak } \\
\text { perpetrators so that Basirompak can } \\
\text { be implemented }\end{array}$ & $\begin{array}{c}\text { Basirompak implementation } \\
\text { process }\end{array}$ & $\begin{array}{c}\text { If guilty, then the victim is } \\
\text { successful in witchcraft; if it turns } \\
\text { out to be innocent, then the target } \\
\text { as the victim will not experience } \\
\text { any influence }\end{array}$ \\
\hline $\begin{array}{c}\text { The applicant submitted the next } \\
\text { process to the Basirompak Actors }\end{array}$ & $\begin{array}{c}\text { Basirompak perpetrators } \\
\text { surrender to God }\end{array}$ & $\begin{array}{c}\text { If the woman's level of error was } \\
\text { severe before Basirompak ended, } \\
\text { the victim had gone crazy }\end{array}$ \\
\hline $\begin{array}{c}\text { The responsibility is already in the } \\
\text { hands of Basirompak }\end{array}$ & $\begin{array}{c}\text { Responsibility is felt to the } \\
\text { afterlife }\end{array}$ & $\begin{array}{c}\text { Responsibilities of the world and } \\
\text { the hereafter }\end{array}$ \\
\hline
\end{tabular}

Basirompak perpetrators are Basirompak executors who get orders from applicants who expect Basirompak to be carried out, if from the targeted party there is no element of error, the Basirompak process will never get the influence of the Basirompak process. Still, if the target victim has a mistake 
fatal, the victim will feel the power of the Basirompak process. In the Basirompak process, the Basirompak actors submit to God's will. The responsibility of Basirompak perpetrators is borne in the afterlife. In contrast, for the applicant, the fault is accepted by the Basirompak perpetrators. For victims of responsibility for their actions, they are taken as punishment in the world and the hereafter. In Saluang Sirompak witchcraft, the economy is borne by the applicant, by negotiating (an agreed agreement) between the applicant and the perpetrator. The amount of economy that is borne by the applicant is solely for the needs of the offerings and the Basirompak process.

Meanwhile, the perpetrator did not get any money from the results of the agreement. The perpetrator only carried out orders from the Penghulu, responsible for carrying out Basirompak, even though there was never a penny in return. The Penghulu did not take the money earmarked for offerings in Basirompak because, in the agreement, there was no wage for the Penghulu and other actors. Another case with the Saluang Sirompak performance, which is intended for entertainment, will be negotiations about the pay. On this occasion, Sirompak actors get money, according to the size of the response from consumers. In performance intended for entertainment, there is no element of witchcraft, such as the Basirompak incident, which was used to use guilty women. The differences between the performances used for the Saluang Sirompak witchcraft, and those for entertainment, are:

- For Basirompak's needs, negotiations between consumers and Basirompak actors are limited to finding a fund agreement to realize the offerings needed by the Actors.

- Entertainment needs a negotiation for an agreement on "wages," because in serving entertainment needs, the actor does not only use part of the offerings in his performance. The result of this negotiation, consumers can provide a down payment as a sign, and after the show is over, the completeness of the negotiated funds is $100 \%$ fulfilled.

In reality, after Basirompak was implemented, men did not marry the women who were used because the conditions of women who had been exposed to Basirompak became crazy and would never recover. Healing can be done by smart people, or to Basirompak perpetrators. Especially for the healing from Basirompak, there is a special message that must be heeded, namely that the victim should never listen to Saluang Sirompak. The woman can recover naturally when she is over 40 years old (stepping on menopause), or after not of productive age (fertile period), but if she does not hear Saluang Sirompak, because it is still crazy, Erianto emphasized that this is indeed not to be married, even though the marriage or marriage of both parties will not last long, for the next few days or months the man will divorce her.

\subsection{Saluang Sirompak}

The making of the Saluang Sirompak instrument involves a unique ritual. The process of ritual is a simple step, the requirements must be met, and nothing should be left behind. The best bamboo is the main requirement in making Saluang Sirompak; giving power lies in the process of cultivating and giving holes in the tone. After the actors cut the bamboo according to the length of the Saluang Sirompak, then the hole distance is determined as a symbol of the residing of the spirits, which are planned to master the tones contained in the Saluang Sirompak hole. The spiritual power of the Saluang Sirompak notes can be achieved through the unnatural stages of death events to be utilized in the cultivation of the five holes of the Saluang Sirompak tone. Each hole is made based on certain death events. The function of each sound or tone produced by a syringe is also supported by the presence of soundhole watchers consisting of the spirits of the deceased and genie, each of which produces a sound or tone that has high spiritual power and can easily affect the victim. The function of the notes produced from each of the holes and gaps can affect the following.

- First Hole.

The first hole inhabited by the spirit of a suicidal person and a genie named Simambau Hitam was used by Basirompak as a medium to darken or close the eyes of the victim's heart. This is intended so that the victim no longer has controlled emotions because genie Simambau Hitam has shut him down. The heartbeat cannot beat regularly; the irregular heartbeat will affect the heart's emotions that are difficult to control.

- Second Hole

The second hole is inhabited by the spirit of a mother who died during childbirth and the genie Simambau Merah (Sirah). The death of a mother who dies during childbirth causes deep 
sadness on the part of the family and the spirit concerned. The role of genie Simambau Merah gave the feeling that the victim was just angry, uncontrollably, so she became crazy.

- Third Hole

The third hole is inhabited by the spirit of the murder victim and the genie Simambau Tungga. The death of someone who was killed is considered something that can kill someone's heart against others. The effect on the victims of Basirompak is that they will have no concern for others, angry emotions, and feelings of wanting to kill. Basirompak perpetrators thought that genie Simambau Tungga was very good at controlling the emotions of a person's soul. The role of genie Simambau Tungga is as a center for the goals to be victims so that there are not many victims or targets other than the intended victim. The combination of the influence of the spirit of the murder victim confuses the heart of the victim and the control of the victim's emotions by genie Simambau Tungga.

- Fourth Hole

The fourth hole is inhabited by the spirit of a champion who died due to a fight with another champion and genie Simambau Barantai. According to the Basirompak doer, the mind, emotions, and conditions at the time of a fight are wholly controlled by the genie who penetrates the realm of the mind and regulates his emotions. Genie Simambau Barantai is used as a stalker who will follow where the victim steps. Genie Simambau Barantai must accompany another genie when it is difficult to find the whereabouts of victims.

- Fifth Hole

The fifth hole is inhabited by the spirits of people who died due to natural accidents (drowning or drowning) and the white genie Simambau. The white Simambau genie is used to protect the Basirompak perpetrator and the person who asks for help from the Basirompak perpetrator. A form of protection is potential victims who protect and know of an attack from Basirompak's activities. Usually, the potential victim who feels that Basirompak's activities will come to the Basirompak perpetrator to protect himself cannot be penetrated by spirituality attacks carried out by genie ordered by Basirompak perpetrators. From this protection, there will be a quarrel between the genie from the protector of the potential victim and the genie, who was sent in the Basirompak process. To see the visual form of Saluang Sirompak, it can be seen in Figure 2.

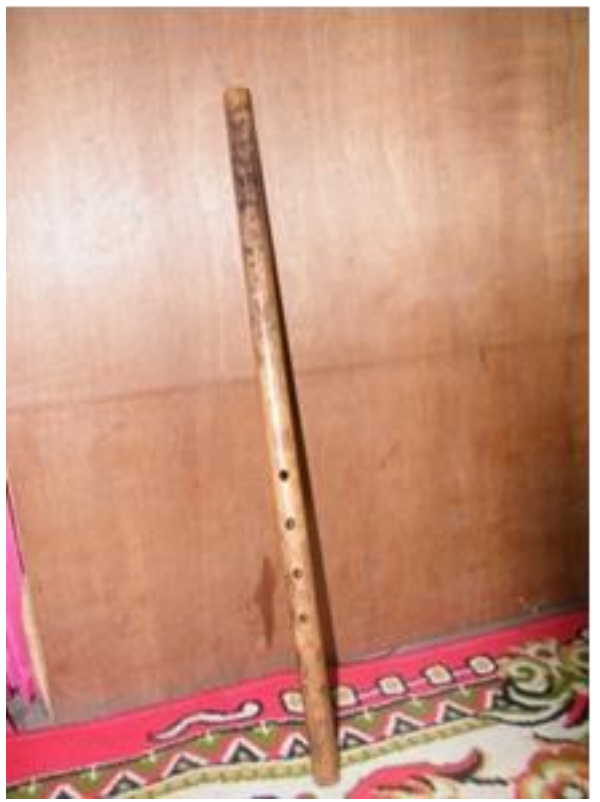

Fig. 2. Saluang Sirompak

The tone produced by each hole depends on how hard or soft the blow is. Each hole has two tonal sounds when the blowing is different; for example, for medium blowing with the holes closed, all produce a tone sound $A+40 \mathrm{mph}$ or a tone $L a+40 \mathrm{mph}$ or $440.40 \mathrm{~Hz}$, then when blown hard, will 
produce the same tone with a distance of one octave higher approx $-880.40 \mathrm{~Hz}$. From the arrangement of the holes that exist with moderate blowing produces notes $A+40 \mathrm{mph}, C 1$ none $+40 \mathrm{mph}, D 1$ none $+5 \mathrm{mph}, E 1$ none $-35 \mathrm{mph}, F 1$ none $+20 \mathrm{mph}$, and Fis 1 none $+5 \mathrm{mph}$. for more details, the technique of covering and the resulting tone is explained as follows.

- All closed holes produce a tone of A + 40 mph or A $L a+40 \mathrm{mph}$ or $440.40 \mathrm{~Hz}$ or $440 \mathrm{~Hz}$ over $40 \mathrm{mph}$.

- The first (bottom) open hole produces the tone $C 1$ none $+40 \mathrm{mph}$ or $D o 1$ none $+40 \mathrm{mph}$ or $523.65 \mathrm{~Hz}$ or $523 \mathrm{~Hz}$ over $65 \mathrm{mph}$.

- The second open hole produces a tone $D 1$ none $+5 \mathrm{mph}$ or tone $\operatorname{Re} 1$ none $+5 \mathrm{mh} 587.38 \mathrm{~Hz}$ or $587 \mathrm{~Hz}$ over $38 \mathrm{mph}$.

- The third open hole produces a tone of $E 1$ none - $35 \mathrm{mph}$ or tone $M i 1$ none - $35 \mathrm{mph} 658.91$ $\mathrm{Hz}$ or $658 \mathrm{~Hz}$ over $91 \mathrm{mph}$.

- The fourth open hole produces a tone of $F 1$ none $+20 \mathrm{mph}$ or a tone of $F a 1$ none $+20 \mathrm{mph}$ $698.66 \mathrm{~Hz}$ or $698 \mathrm{~Hz}$ over $66 \mathrm{mph}$.

- The fifth open all holes produce the tone Fis 1 none $+5 \mathrm{mph}$ or tone Fis 1 none $+5 \mathrm{mph}$ or $740.04 \mathrm{~Hz}$ or $740 \mathrm{~Hz}$ over $0.4 \mathrm{mph}$.

For loud blasts, all the notes produced are the same as those produced with moderate puffs, but the result is an octave higher. The Saluang Sirompak notation can be seen in the Dendang melody in the Imbauan section, as seen in the notation in Figure 3.

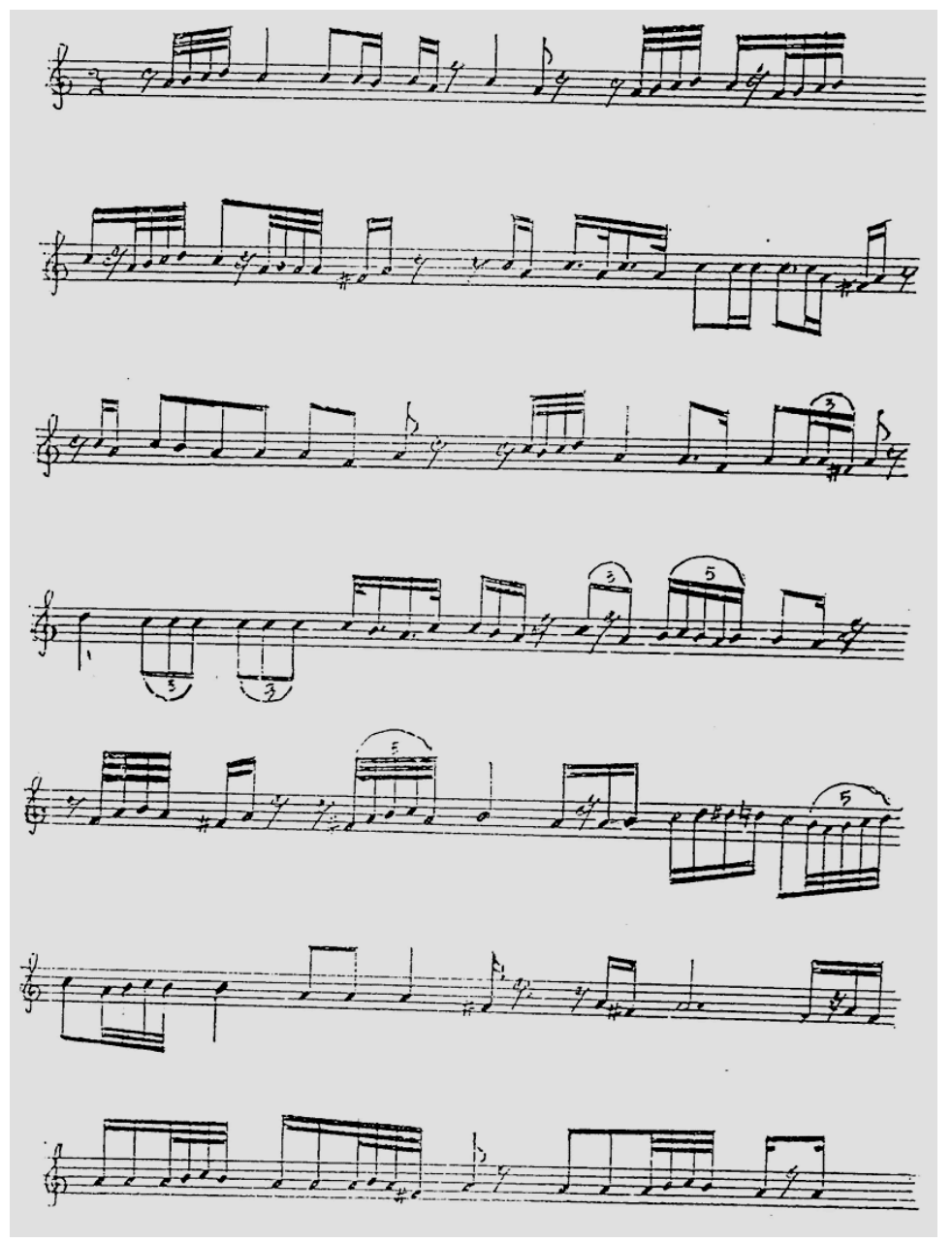

The following notation is on the next page. 


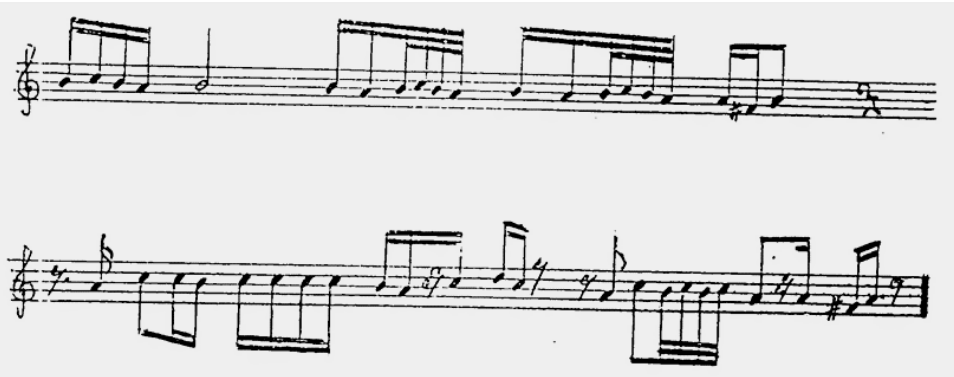

Fig. 3. Dendang Melody Notation on Saluang Sirompak Imbauan Section

The Saluang Sirompak musical performance, called Basirompak, is a means of taking a man's grudge against the woman who has insulted him. Before the Basirompak activity took place, there was a dialogue between the Basirompak perpetrators and the petitioner. At this stage, there would be a discussion process regarding the appropriateness of the target to become a victim. If women are deemed fit to be attacked, Basirompak will be held, but if it turns out that the target is not worthy of being the target and the victim, then a witchcraft reversal will occur. Women who were previously targeted as victims cannot be penetrated because of their innocence, the impact of the recklessness committed by the male applicant. Witchcraft from Basirompak's activities will target the male party as the applicant.

\section{Conclusion}

The target victims of the Saluang Sirompak performance in the Basirompak activities were only for women. Witchcraft using Saluang Sirompak has an unfortunate effect on the victim or a woman. Witchcraft in Basirompak activities can determine what is right and wrong; if women were not mistaken, they would not have become victims of witchcraft from Basirompak's activities. Besides functioning for witchcraft, the performance of Saluang Sirompak in its function as entertainment also still has magic power (for those who are victims). In the Saluang Sirompak performance and the Basirompak ritual, this ritual has standard rules that must not be violated, such as the recitation of mantras, the location of the way, the time of execution, the offerings, and the equipment used. Saluang Sirompak is placed in the witchcraft procession against women. In subsequent developments, the Saluang Sirompak dish shifted slightly from the previous one, which was used for witchcraft purposes now also serves as entertainment.

\section{References}

[1] P. G. Zimbardo, "Optimizing the Power and Magic of Teaching," J. Soc. Clin. Psychol., vol. 24, no. 1, pp. 11-21, Jan. 2005, doi: 10.1521/jscp.24.1.11.59173.

[2] D. E. R. George, "Ritual Drama: Between Mysticism and Magic," Asian Theatr. J., vol. 4, no. 2, p. 127, 1987, doi: $10.2307 / 1124188$.

[3] M. Adinkrah, "Witchcraft Themes in Popular Ghanaian Music," Pop. Music Soc., vol. 31, no. 3, pp. 299311, Jul. 2008, doi: 10.1080/03007760802009791.

[4] R. Morris, "Witchcraft," Soc. Text, vol. 26, no. 2, pp. 113-133, 2008, doi: 10.1215/01642472-2007-033.

[5] C. Conrad, "Music for healing: from magic to medicine," Lancet, vol. 376, no. 9757, pp. 1980-1981, Dec. 2010, doi: 10.1016/S0140-6736(10)62251-9.

[6] P. S. Marra and F. Trotta, "Sound, music and magic in football stadiums," Pop. Music, vol. 38, no. 01, pp. 73-89, Jan. 2019, doi: 10.1017/S0261143018000727.

[7] C. Pegg, "Ritual, religion and magic in West Mongolian (Oirad) heroic epic performance," Br. $J$. Ethnomusicol., vol. 4, no. 1, pp. 77-99, Jan. 1995, doi: 10.1080/09681229508567239.

[8] R. C. Jankowsky, "Music, Spirit Possession and the In-Between: Ethnomusicological Inquiry and the Challenge of Trance," Ethnomusicol. Forum, vol. 16, no. 2, pp. 185-208, Nov. 2007, doi: 10.1080/17411910701554021. 
[9] K. Roulston, "Mapping the possibilities of qualitative research in music education: a primer," Music Educ. Res., vol. 8, no. 2, pp. 153-173, Jul. 2006, doi: 10.1080/14613800600779592.

[10] J. Hockey and M. Forsey, "Ethnography Is Not Participant Observation: Reflections on the Interview as Participatory Qualitative Research," in The Interview, Routledge, 2020, pp. 69-87. available at: Google Books.

[11] K. Aigen, "An analysis of qualitative music therapy research reports 1987-2006: Articles and book chapters," Arts Psychother., vol. 35, no. 4, pp. 251-261, Jan. 2008, doi: 10.1016/j.aip.2008.05.001.

[12] M. Munir and M. G. R. Pandin, "The Local Genius Values of Minangkabau Society," in Proceedings of the International Conference of Communication Science Research (ICCSR 2018), 2018, doi: 10.2991/iccsr-18.2018.67.

[13] E. Blackwood, "Representing Women: The Politics of Minangkabau Adat Writings," J. Asian Stud., vol. 60, no. 1, pp. 125-149, Feb. 2001, doi: 10.2307/2659507.

[14] M. Munir and M. G. Rumambo Pandin, "The Values Of Bundo Kanduang Ethics In Indonesia.," Talent Dev. Excell., vol. 12, no. 1, 2020. available at: Google Scholar. 